\title{
PENERAPAN METODE LANGSUNG DALAM PEMBELAJARAN BAHASA ARAB
}

\author{
Anwar Abd. Rahman \\ Email: \\ Universitas Islam Negeri (UIN) Alauddin Makassar
}

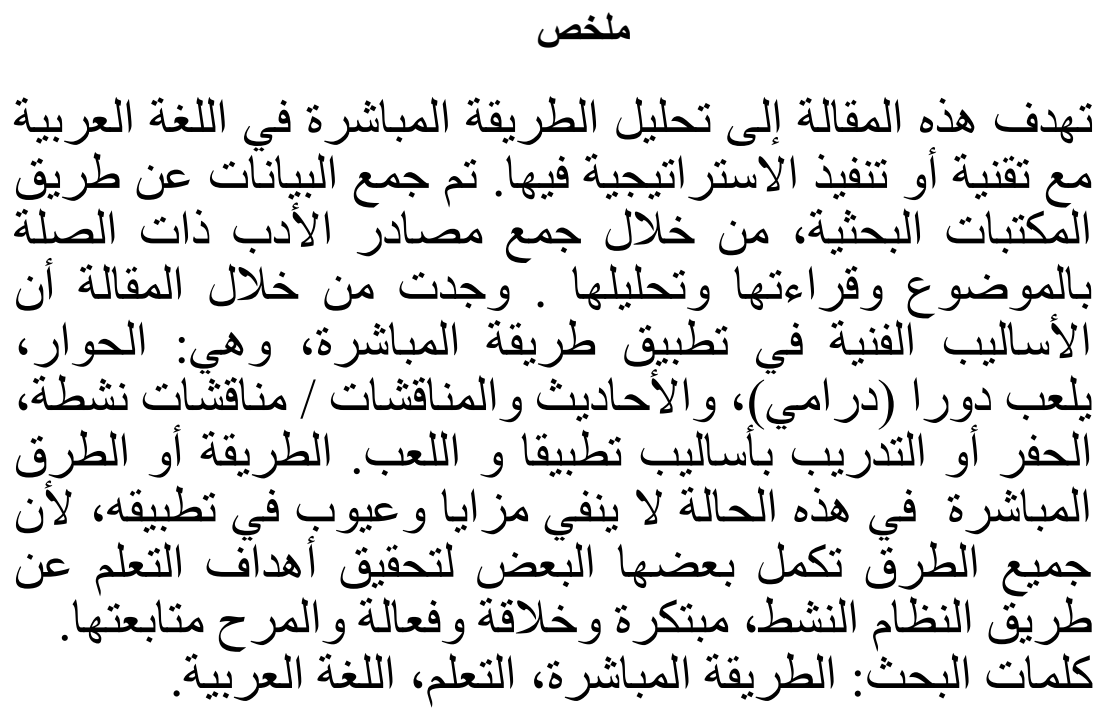

\begin{abstract}
Abstrak
Artikel ini bertujuan untuk menganalisi metode langsung dalam bahasa Arab beserta teknik atau strategi penerapannya. Data dikumpulkan berdasarkan penelitian pustaka, yaitu dengan mengumpulkan, membaca dan menganalisa sumber bacaan terkait tema. Artikel ini menemukan bahwa tedapat metode dalam penerapan metode langsung, yaitu: Tanya jawab, bermain peran (dramatisasi), percakapan, diskusi/debat aktif, metode drill atau latihan siap dengan uslub terapan dan bermain. Metode langsung atau metode mubasyarah dalam hal ini tidak menafikan kelebihan dan kelemahannya dalam penerapannya, karena semua metode saling melengkapi dalam merealisasikan tujuan pembelajaran yang ditempuh dengan sistem Pembelajaran Aktif, Inovatif, Kreatif, Efektif dan Menyenangkan (PAIKEM).
\end{abstract}

Kata kunci: Metode langsung; pembelajaran; bahasa Arab. 


\section{A. Pendahuluan}

Dalam proses pembelajaran bahasa Arab akan terjadi interaksi antara guru dan anak didik. Belajar merupakan kegiatan yang dilakukan oleh anak didik, sedangkan mengajar merupakan kegiatan yang dilakukan oleh sang guru. Kegiatan mengajar guru sangat mempengaruhi kegiatan belajar anak didik. Kegiatan belajar-mengajar bahasa Arab melibatkan beberapa komponen, yaitu peserta didik, guru (pendidik), tujuan pembelajaran, isi pelajaran, metode mengajar, media, dan evaluasi.

Tujuan pembelajaran adalah perubahan perilaku dan tingkah laku yang positif dari peserta didik setelah mengikuti kegiatan belajar-mengajar, baik perubahan secara psikologis dalam tingkah laku (over behaviour), motorik, maupun gaya hidupnya. Sementara itu, tujuan pembelajaran bahasa Arab secara umum adalah agar peserta didik mampu mengusai empat keterampilan bahasa, yaitu keterampilan menyimak, keterampilan membaca, keterampilan berbicara, dan keterampilan menulis. Untuk memperoleh keempat keterampilan ini, ada beberapa hal yang perlu diperhatikan oleh pendidik, salah satu di antaranya yang menurut hemat pemakalah yang dianggap penting adalah metode mengajar.

Metode mengajar dalam dunia pendidikan perlu dimiliki oleh pendidik karena keberhasilan proses belajar-mengajar bergantung pada cara/mengajar gurunya. Jika cara mengajar gurunya enak menurut siswa, maka siswa akan tekun, rajin, dan antusias menerima pelajaran yang diberikan sehingga diharapkan akan terjadi perubahan sesuai dengan tujuan pembelajaran.

Bahasa Arab (asing) berbeda dengan belajar bahasa ibu, oleh karena itu prinsip dasar pengajarannya harus berbeda, baik menyangkut metode (model pengajaran). Setiap anak manusia pada dasarnya mempunyai kemampuan untuk menguasai setiap bahasa, walaupun dalam kadar dan dorongan yang berbeda. Adapun diantara perbedaan-perbedaan tersebut adalah tujuan-tujuan pengajaran yang ingin dicapai, kemampuan dasar yang dimiliki, motivasi yang ada di dalam diri dan minat serta ketekunannya.

Maka berangkat dari sinilah kami mencoba untuk mengupas secara singkat tentang metode mubāsyaroh ( langsung ) dalam makalah ini. Karena kami merasa bahwa penting sekali dalam penggunaan sebuah metode untuk diterapkan dalam pembelajaran yang berkaitan dengan bahasa.

Dari latar belakang yang telah dipaparkan diatas maka dapat diambil beberapa rumusan masalah, diantaranya

1. Apa yang dimaksud dengan metode langsung?

2. Bagaimana latar belakang munculnya metode langsung?

3. Bagaimana teknik-teknik penerapan metode langsung dalam pembelajaran bahasa Arab?

4. Apa kelebihan dan kekurangan yang dikandung metode langsung dalam pembelajaran bahasa Arab? 


\section{B. Pengertian Metode Langsung}

Direct method atau metode langsung yaitu suatu cara menyajikan materi pelajaran Bahasa Asing dimana guru langsung menggunakan bahasa asing tersebut sebagai bahasa pengantar, dan tanpa menggunakan bahasa anak didik sedikit pun dalam mengajar. Jika ada suatu kata- kata yang sulit dimengerti anak didik, guru dapat mengartikan dengan menggunakan alat peraga, mendemonstrasiakan, menggambarkan dan lain- lain. ${ }^{1}$

Metode ini lahir sebagai reaksi terhadap penggunaan metode nahwu wa al-tarjamah yang mengajarkan bahasa seperti bahasa yang mati. Di awal abad ke-19 pada tahun $1850 \mathrm{M}$. Telah banyak muncul propaganda yang mengkampanyekan agar menjadikan pengajaran bahasa asing itu hidup, menyenangkan dan efektif. propoganda ini menuntut adanya perubahan yang mendasar dalam metode pembelajaran bahasa asing. ${ }^{2}$ Sehingga secara cepat lahirlah metode pembelajaran baru yang disebut dengan metode langsung pada tahun $1901 \mathrm{M}$. yang dibakukan dengan edaran kementerian pengajaran Prancis di Prancis. Kemudian setahun kemudain metode ini ditetapkan sebagai satu-satunya metode yang diakui di Prancis. ${ }^{3}$

Sedangkan menurut J.C. Richards seperti dikutip Anton D. Pratomo bahwa metode langsung yang sering disebut sebagai direct method sebenarnya lahir dari metode alamiah (natural method) yaitu suatu pembelajaran bahasa yang dialami anakanak kecil ketika memulai belajar berbahasa. Artinya bahwa bahasa adalah sesuatu yang hidup, oleh karena itu harus dikomunikasikan dan dilatih terus sebagaimana anak kecil belajar bahasa. Metode langsung diarahkan kepada keberhasilan pada bahasa target dengan mengenal kosakata dan kalimat-kalimat sehari-hari, menggunakan komunikasi lisan dan tata bahasa diajarkan secara induktif. Hal-hal baru diperkenalkan secara lisan dengan melalui peragaan, barang-barang nyata, gambar-gambar. Sedangkan kosakata yang bersifat abstrak diperkenalkan melalui asosiasi ide. Berbicara dan mendengarkan diajarkan sekaligus dengan menekankan pada ketepatan ucapan dan tata bahasa.

Metode langsung sebenarnya berdasarkan konsep Jacob Gouin bahwa pembelajaran bahasa perlu dilakukan dengan dramatisasi dan peragaan dengan menggunakan prinsip-prinsip psikologi modern seperti asosiasi, visualisasi, belajar memali panca indera, hal-hal menarik, belajar melalui permainan dan aktifitas keseharian yang dikenal oleh anak didik. Karena bagi Gouin kalimat adalah unit bahasa yang fundamental dan setiap kalimat harus dihubungkan dengan kalimat lainnya untuk membentuk satu rangkaian. ${ }^{4}$ Sehingga bahasa itu dengan cara

1 Drs. H. Ahmad Izzan,M Ag. Metodologi Pembelajaran Bahasa Arab. Bandung: Humaniora.2009,86.

${ }^{2}$ M. Abdul Hamid, et al., Pembelajaran Bahasa Arab: Pendekatan. Metode, Strategi, Materi dan Media (Cet. I; Malang: UIN-Malang Press, 2008), h. h. 23.

${ }^{3}$ Imam Makruf, Strategi Pembelajaran Bahasa Arab Aktif (Cet. I; Semarang: Need's Press, 2009), h. 40.

${ }^{4}$ Imam Makruf, Strategi Pembelajaran Bahasa Arab Aktif (Cet. I; Semarang: Need's Press, 2009), h. 40. 
dipercakapkan dan dikomunikasikan agar hidup dan aktif sesuai dengan fungsinya dan tidak mati serta pasif. Olehnya itu pembelajaran bahasa sebagai bahasa kedua harus lebih seperti pembelajaran bahasa pertama, banyak interaksi lisan, dan sedikit atau tidak ada aturan gramatikal analisis. Pelajaran dimulai dengan dialog menggunakan modern gaya bicara dalam bahasa target. Bahan pertama adalah disajikan secara lisan dengan tindakan atau gambar. Bahasa ibu tidak pernah digunakan. Tidak ada terjemahan. Pilihan jenis latihan adalah rangkaian pertanyaan dalam bahasa target berdasarkan dialog atau anecdotal naratif. Pertanyaan akan dijawab dalam bahasa target. Tata bahasa yang diajarkan inductively (bersifat induktif).

Oleh karena pembelajaran bahasa arab sebagai bahasa kedua, menjadi sasaran utama kompetensi komunikatif maka pendekatan yang relevan untuk metode ini adalah pendekatan komunikatif (communicative approach) dan pendekatan humanisme (humanistic approach) ${ }^{5}$.

Dari semua perspektif di atas, namun adapun asumsi yang paling mendasari sehingga metode ini berkembang dan dikembangkan adalah proses belajar bahasa kedua atau bahasa asing sama dengan belajar bahasa asing yaitu dengan penggunaan bahasa secara langsung dan intensif dalam komunikasi, dan dengan menyimak dan berbicara, sedangkan mengarang dan membaca dikembangkan kemudian. ${ }^{6}$

Merujuk kembali kepada prinsip-prinsip pembelajaran bahasa Arab (atau bahasa asing lainnya). Maka metode langsung ini, sejalan ${ }^{7}$ dengan hal tersebut yang di mana ada lima prinsip yang disebutkan oleh Kamal Ibrahim Badri dan Mamduh Nuruddin sebagaimana dikutip oleh Imam Makruf dalam pembelajaran bahasa arab yaitu:

1. Prinsip perioritas atau mendahulukan yang lebih utama (أولويآت التقديم)

Prioritas yang di maksud tersebut adalah sebagai berikut:

a. mendengar (إستماع) dan berbicara (كلام) terlebih dahulu diajarkan dari pada menulis (كتابة). Prinsip ini berangkat dari asumsi bahwa pengajaran bahasa yang baik adalah pengajaran yang sesuai dengan perkembangan bahasa yang alami pada manusia, yaitu setiap anak akan mengawali perkembangan bahasanya dari mendengar dan memperhatikan kemudian menirukan. Hal itu menunjukan bahwa kemampuan mendengar/menyimak

${ }^{5}$ Pendekatan Humanisme (humanistic approach) yaitu sebuah pendekatan yang memberikan perhatian kepada pembelajar sebagai manusia yang aktif, tidak menganggapnya sebagai benda yang merekam seperangkat pengetahuan yang pasif. pendekatan ini bertujuan untuk mempererat hubungan antara manusia dengan berbagai ragam budaya dan pengalaman yang bisa memenuhi kebutuhan pembelajar untuk aktualisasi diri. Selengkapnya lihat buku Pembelajaran Bahasa Arab: pendekatan, Metode, Strategi, Materi dan Media oleh M. Abdul Hamid h. 5.

${ }^{6}$ Lihat Ahmad Fuad Effendy, Metodologi Pengajaran Bahasa Arab (Cet. IV; Malang: Misykat, 2009), h. 46.

${ }^{7}$ Dalam artian bahwa metode langsung yang fokusnya lebih berorientasi kepada manusia sebagai manusia yang aktif dan bahasa sebagai alat bukan seabagai budaya ilmu, sehingga kemampuan mendengar (mahārah al-istimā') dan kemampuan berbicara (mahārah al-kalām) lebih diperioritaskan. 
harus lebih dahulu dibina, kemudian kemmpuan menirukan ucapan. lalu aspek lainnya seperti membaca (تراءة) dan menulis (كتابة).

b. mengajarkan kalimat (جملة) sebelum mengajarkan kata-kata (كلمات) (كمات).

c. mengajarkan kosakata (مفردات) yang fungsional sebelum mufradat lainnya.

d. mengajarkan bahasa dengan kecepatan yang biasa digunakan pemilik bahasa aslinya.

2. Prinsip ketepatan atau korektisitas (الدقة)

3. Prinsip bertahap (التدرج)

4. Prinsip aspek motivasi (عنصر التشويق)

5. Prinsip baku dan mendasar (الصلابة و المتنانة) berikut:

Adapun yang menjadi karakteristik dari metode lansung ini adalah, seagai

1. Tujuan dasar yang diharapkan adalah mengembangkan kemampuan anak didik untuk berpikir dengan bahasa Arab bukan dengan bahasa ibu anak didik,

2. Bahasa Arab menjadi bahasa pengantar dalam pembelajaran bahasa Arab,

3. Percakapan antar individu merupakan bentuk pertama dan yang umum untuk digunakan dalam masyarakat, sehingga pada awal pembelajaran bahasa Arab hendaknya percakapan mereka menggunakan kosakata dan susunan kalimat sesuai dengan maksud dan tujuan belajar anak didik,

4. Di awal pembelajaran anak didik dikondisikan untuk mendengarkan kalimatkalimat sempurna dan mempunyai makna yang jelas, sehingga anak didik mampu dan mudah memahaminya,

5. Teks Arab tidak disajikan kepada anak didik sebelum mereka mengenal suara, kosakata serta susunan yang ada di dalamnya. Dan juga siswa tidak menulis teks Arab sebelum mereka bisa membaca dengan baik serta memahaminya,

6. Dalam proses pengajaran senantiasa menggunakan alat bantu (alat peraga) baik alat peraga langsung, tidak langsung (benda tiruan) maupun peragaan melalui simbol-simbol atau gerakan-gerakan tertentu,

7. Garamatika diajarkan hanya berdifat sambil lalu atau secara induktif dan anak didik tidak dituntut untuk menghafal rumus-rumus gramatika, tetapi yang utama adalah anak didik mampu mengucapkan bahasa secara baik,

8. Guru lebih banyak menggunakan waktunya untuk tanya jawab dengan anak didik,

9. Sebagian besar waktu pembelajaran digunakan untuk latihan bahasa, seperti imla', mengulang cerita atau mengarang bebas,

10. Perhatian metode ini lebih banyak pada pengembangan kemampuan siswa untuk berbicara dibandingkan pada aspek yang lain.

${ }^{8}$ Imam Makruf, Strategi Pembelajaran Bahasa Arab Aktif (Cet. I; Semarang: Need's Press, 2009), h. 42.

${ }^{9}$ Lihat Rusdi Ahmad Tu'aimah, Ta'lìm al-'Arabiyyah li ghair al-Nātiqīna bihā: manāhijuhu wa asālībuhu, (Mesir: ISESCO \& WICS, $1410 \mathrm{H}-1989$ M), h. 129-130. 


\section{Latar Belakang Munculnya Metode Langsung}

Metode ini muncul pada abad ke 19 dan berkembang pada abad ke 20. Karena metode ini mempunyai pemikiran baru sehingga berlawanan dengan metode qowa'id dan terjemah yang digunakan oleh para pemula dalam belajar bahasa. ${ }^{10}$ Metode langsung dikembangkan oleh carles berlitz, seorang ahli dalam pengajaran bahasa, di Jerman . Pada saat itu memang metode tata bahasa dan terjemah merupakan metode pengajaran bahasa kedua dan asing yang populer. Akan tetapi ditengah kepopulerannya muncul banyak ketidak puasan di banyak kalangan, sehingga munculah kritik bahkan penolakan terhadap metode ini. Secara lebih rinci faktorfaktor itu adalah :

1. Pada saat penduduk Eropa semakin bertambah, tingkat komunikasi mereka semakin kompleks. Hal ini mengakibatkan kebutuhan mereka untuk menguasai satu bahasa ( misal, bahasa Inggris) sebagai Lingua Franca secara aktif dan produktif semakin mendesak. Buku-buku sumber yang ditemukan pada waktu itu kurang memuaskan mereka, karena pada umumnya tidak mengajarkan penggunaan bahasa tujuan secara praktis dan efektif, melainkan berbicara tentang bahasa tujuan.

2. Dibeberapa negara Eropa pada waktu itu, pendekatan-pendekatan baru pada pengajaran bahasa tujuan yang dicetuskan oleh para ahli pengajaran bahasa secara terpisah-pisah memberikan ide kepada guru bahasa tujuan untuk mengangkat metode lain yang dipandang lebih baik untuk mengajarkan bahasa tujuan. Hal ini membuka jalan mereka untuk memunculkan metode langsung.

Meskipun metode langsung merupakan reaksi kuat terhadap metode tata bahasa dan terjemah, namun orang-orang telah lebih dulu menggunakannya dalam mengajarkan bahasa asing. Nababan, menyebutkan bahwa penggunaannya telah berlangsung sekitar abad ke-15 ketika para pemuda Romawi diberi pelajaran bahasa Yunani oleh guru-guru bahasa dari Yunani. Namun penggunaan metode langsung pada waktu itu tidak benar-benar sebagai metode langsung.

\section{Teknik-teknik Penerapan Metode Langsung (الطريقة المباثرة) dalam PembelajaranBahasa Arab}

Untuk mengaplikasikan metode langsung dalam pengajaran bahasa asing, dalam hal ini Bahasa Arab, kita perlu melihat konsep dasar metode ini sebagaimana dijelaskan diatas. Aplikasi berikut ini hanya contoh saja, tidak meruakan kemestian, maka penggunaan selanjutnya diserahkan kepada pengajar sesuai situasi dan kondisi, dengan catatan tidak bertentangan dengan konsep dasar metode ini. Secara umum langkah yang dapat dilakukan adalah sebagai berikut:

1. Pendahuluan, memuat berbagai hal yang berkaitan dengan materi yang akan disajikan baik berupa apresesi, atau tes awal tentang meteri atau yang lainnya.

2. Guru memberi materi berupa dialog-dialog pendek yang riek, dengan bahasa yang biasanya digunakan sehari-hari secara berulang-ulang. Materi ini mula-mula

10 Mukhtar Thohir Husain, Ta'līm al-'Arabiyyah li ghair al-Nātiqīna bihā, (Haram: Dar al-Alamiyah), hal. 230. 
disajikan secara lisan dengan gerakan-gerakan, isyarat-isyarat dramatisasi atau gambar-gambar. Jika sudah mantab bias dikembangkan kedalam tulisan. Misalnya:

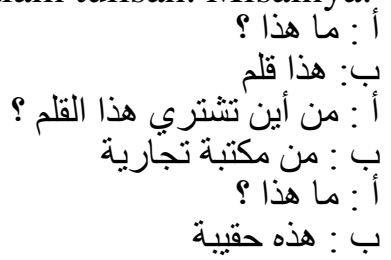

3. Pelajar diarahkan untuk disiplin menyimak dialog-dialog tersebut, lalu meniru dialog-dialog yang disajikan sampai lancar.

4. Para pelajar dibimbing menerapkan dialog-dialog itu dengan teman-temannya secara bergiliran. Pelajar yang sudah maju diberi kesempatan untuk mengadakan dialog lain yang dianalogikan dengan contoh yang diberikan oleh guru.

5. Struktur/tata bahasa diberikan bukan dengan menganalisa nahwu, melainkan dengan memberikan contoh-contoh secara lisan yang sedapat mungkin menarik perhatian pelajar untuk percakapan di atas ada pola mubtadak-khobar, dalam hal ini cukup dengan menyebutkan:

atau pola shifah-maushuf, cukup dengan menyebutkan:

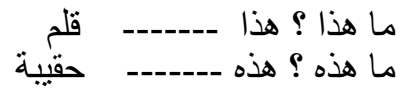

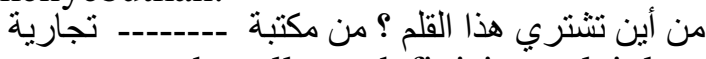
tentu saja tidak dengan menjelaskan atau menghapalkan definisi, melainkan dengan mengulang-ulang contoh secara lisan saambil menunjukkan pasangannya agar pelajar tidak keliru antara mudzakkar dan muaannats. Akan tetapai pengajaran ini bersifat situasional, induktif dan tidak menjadi prioritas.

6. Sebagai penutup, jika diperlukan, evaluasi akhir berupa pertanyaan-pertanyaan dialog yang harus dijawab oleh pelajar sebagaimana pola-pola dialog diatas. Pelaksanaannya bisa individual atau kelompok tergantung situasi dan kondisi.

Menurut Yayat Hidayat, karena penekanan metode ini pada aspek yang benar, maka memerlukan hal-hal berikut:

a. Materi pengajaran pada tahap awal berupa latihan oral (syafawiyyah)

b. Materi dilanjutkan dengan latihan menuturkan kata-kata sederhana (kalām), baik kata benda (isim) atau kata kerja ( $\left.f{ }^{\prime} i l\right)$ yang sering didengar oleh peserta didik.

c. Materi dilanjutkan dengan latihan penuturan kalimat sederhana dengan menggunakan kalimat yang merupakan aktifitas peserta didik sehari-hari.

d. Peserta didik diberikan kesempatan untuk berlatih dengan cara tanya jawab dengan guru/sesamanya.

e. Materi Qira'ah harus disertai diskusi dengan bahasa Arab, baik dalam menjelaskan makna yang terkandung di dalam bahan bacaan ataupun jabatan setiap kata dalam kalimat.

f. Materi gramatika diajarkan di sela-sela pengajaran, namun tidak secara mendetail.

g. Materi menulis (kitābah) diajarkan dengan latihan menulis kalimat sederhana yang telah dikenal/diajarkan pada peserta didik. 
h. Selama proses pengajaran hendaknya dibantu dengan alat peraga/media yang memadai.

Berikut contohnya di bawah ini dan langkah-langkahnya:

1) Pembelajaran percakapan (حوار أو تعبير شفوي مصتّر )
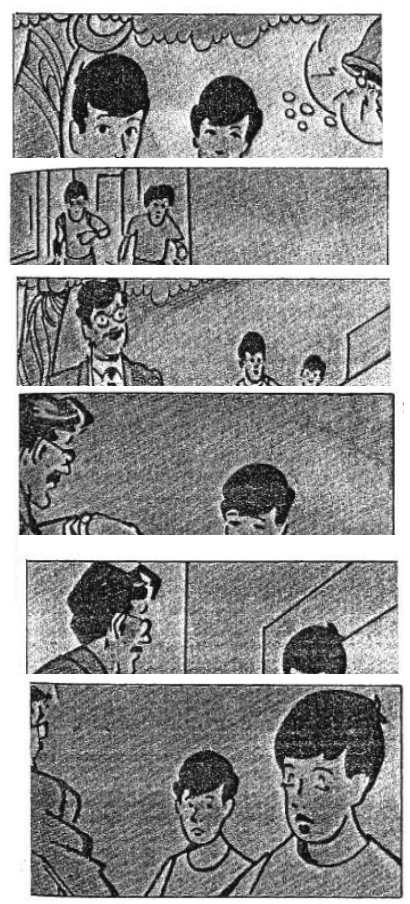

$$
\begin{aligned}
& \text { حمزة : إستمع يا حسن ! ما هذا؟ } \\
& \text { حسن : هذا صوت الجرس. } \\
& \text { حمزة أسرع يا زكريا. } \\
& \text { حسن : أسرع يا همزة. }
\end{aligned}
$$

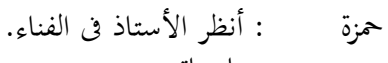

$$
\begin{aligned}
& \text { حسن : يا ساتر. } \\
& \text { الأستاذ أنت متأخر اليوم يا ممزة. } \\
& \text { الهزة : آسف با أستاذ. } \\
& \text { الأستاذ : أسرع إلى الفصل. } \\
& \text { الأستاذ وأنت متأخر اليوم يا حسن. } \\
& \text { حسن : آسف يا أستاذ. } \\
& \text { الأستاذ : اسرع إلى الفصل. } \\
& \text { حمزة وحسن :حاضر يا أستاذ. }
\end{aligned}
$$

Langkah-langkahnya:

a) Mendengar (buku di tutup), dengan aba-aba "dengarkan baik-baik kemudian baca percakapannya atau tulis".

b) Mendengar dan memahami (buku di buka), dengan aba-aba "lihat ke pelajaran dan dengarkan baik-baik". Guru membacakan hiwār dengan tertib kemudian diulangi sekitar tiga kali. Apabila anak didik sulit memahami hiwār dari gambar, maka jelaskan dengan menggunakan alat peraga dan sedapat mungkin tidak diterjemahkan dalam bahasa ibu kecuali darurat.

c) Mendengar (buku di tutup), dengan aba-aba "dengarkan baik-baik, guru membacakannya dengan suara yang jelas dan mengulanginya sampai tiga kali”.

d) Mendengar dan anak didik mengulangi secara berjamaah (buku dibuka). Guru memakai alat peraga atau kedua tangan agar anak didik memahami dan siap mengulangi secara berjamaah setelah guru membaca.

e) Mendengar dan mengulangi secara berjamaah (buku di buka). Guru membagi dalam tiga kelompok (A, B dan $\mathrm{C}$ misalnya) dan masing-masing kelompok

11 Lihat Yayat Hidayat, Studi Prinsip Dasar Metode Pengajaran Bahasa Arab, pada http://arabicforall.or.id/metode/studi-prinsip-dasar-metode-pengajaran-bahasa-arab/ diunduh pada tanggal 18 Mei 2016 Jam 14.45 
menyahut. Kelompok A misalnya sebagai Hamzah. dan B sebagai Hasan, kemudian $\mathrm{C}$ sebagai Guru.

f) Mendengar dan anak didik mengulangi perorangan (buku di buka).

g) Praktek. Guru meminta anak didik masing-masing tiga orang, ada yang berlaku sebagai Hamzah, Hasan dan Guru. Kemudian anak didik mempraktekkannya di hadapan teman-temannya dan seterusnya. ${ }^{12}$

2) Pembelajaran tanya jawab dalam bentuk gambar kemudian di bentuk dalam sebuah cerita (تعبير شفوي مصّور
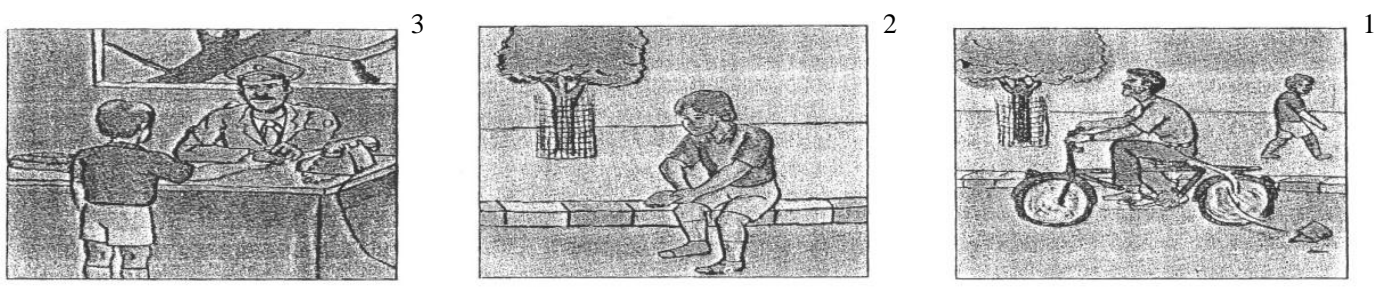

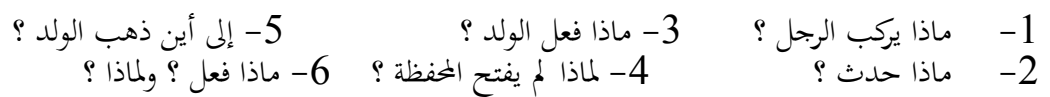
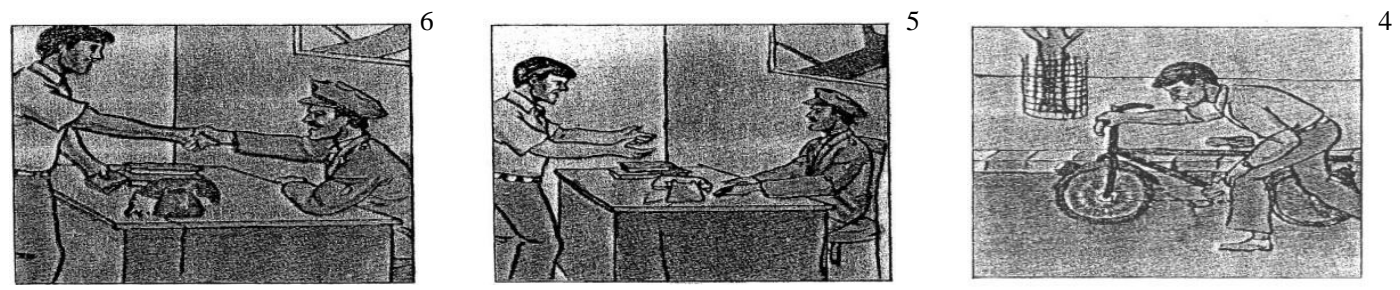

$$
\begin{aligned}
& \text { 7- }
\end{aligned}
$$

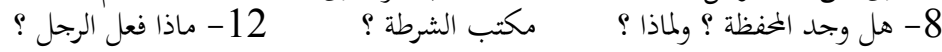

Langkah-langkahnya:

a) Anak didik diminta untuk membuka buku dan memperhatikan gambar dengan baik.

b) Anak didik diminta untuk memperhatikan gambar pertama.

c) Guru membacakan soal gambar pertama dan meminta salah satu dari anak didik untuk menjawabnya. Apabila salah, berikan kesempatan kepada peserta yang lain.

d) Apabila anak didik kesulitan dalam menjawab, guru membacakannya dengan buku sang guru.

e) Lakukan terus menerus sampai akhir pertanyaan dari gambar.

f) Setelah semuanya telah terjawab, minta kepada peserta untuk membuatnya dalam sebuah cerita berdasarkan jawaban sebelumnya.

g) Pilih sebagian peserta untuk membuatnya dalam satu bentuk cerita.

${ }^{12}$ Lihat Mahmud Isma'il Shina, et al., Murs\id al-Mu'allim fĩ Tadrīs al-Lughah $a l$ 'Arabiyyah li ghair al-Nātiq̄̄na bihā (Cet. II; t.tp: Maktab al-Tarbiyyah al-'Arabī li Dual al-Khalīj), h. 140-144. 
h) Apabila setelah selesai dibuat dalam satu cerita suruh minta di kumpul dan diterima sekalipun ada yang tidak sesuai.

i) Apabila peserta kesulitan dalam membuat dalam bentuk satu cerita, guru membacakan contohnya yang senada. ${ }^{13}$

3) Pembelajaran dalam bentuk Drill (latihan siap).

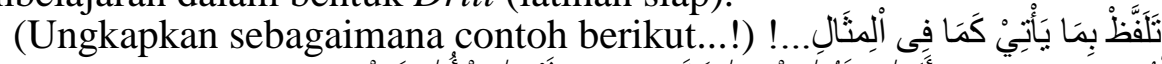

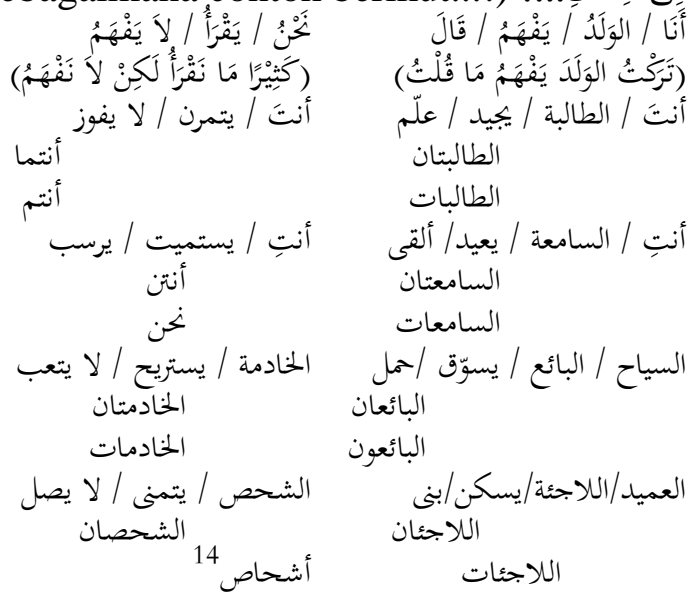

$$
\begin{aligned}
& \text { أَنَاً / قَلَمُ / يَكْتُـُ }
\end{aligned}
$$

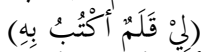

$$
\begin{aligned}
& \text { أنتِّ / كيفية / يَهِهم } \\
& \text { كيفيتان } \\
& \text { كيفيات } \\
& \text { أنتما / نظارة / يبصر } \\
& \text { نظارتان } \\
& \text { نظارات } \\
& \text { انتم / طريقة / يشتهر } \\
& \text { طريقتان } \\
& \text { طرائق } \\
& \text { أنتن / لغة / يتحدث } \\
& \text { لغاتان } \\
& \text { لغات }
\end{aligned}
$$

Langkah-langkahnya:

a) Guru membacakan lebih awal secara keseluruhan

b) Guru menjelaskannya dengan jelas kolom per kolom

c) Guru memberikan pemahaman lebih awal seperti contoh yang diberikan.

d) Guru meminta satu persatu untuk melafalkannya seperti yang diminta oleh soal.

e) Guru meroling secara terib dan berurut untuk menjawabnya secara langsung, dan seterusnya.

Teknik penerapan metode langsung dalam pembelajaran bahasa Arab sangat banyak dan bervarian. Karena metode langsung menekankan adanya dan menuntut pembelajaran bahasa Arab dengan aktif, maka secara otomatis anak didik juga terlibat langsung dan lebih proaktif dikarenakan sang guru menjadi pengarah, fasilitator dan mediator.

Di antara teknik atau starategi yang bisa diterapkan dalam pembelajaran bahasa Arab dengan menggunakan metode langsung secara garis besar menurut hemat penulis adalah sebagai berikut:

1. Tanya jawab (التسائل أو الأسالة و الإجابة)

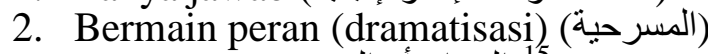

3. Percakapan (الحوار أو التعبير)

${ }^{13}$ Mahmud Isma'il Shina, et al., Murs id al-Mu'allim fĩ Tadrīs al-Lughah al-'Arabiyyah li ghair al-Nātiqīna bihā (Cet. II; t.tp: Maktab al-Tarbiyyah al-`Arab̄̄ li Dual al-Khalīj), h. 191-193.

${ }^{14}$ Lihat Muhammad Saleh bin Syamsuri al-Butān̄̄, al-Ta'bīr al-Muwajjah 'al al-Asālīb alSyāi'ah al-Isti'māl > (Jilid I, Cet. I; Makassar: t.p., 2006), h. 2, 9, 17. 
4. Diskusi/debat aktif (المناقتشة أو المجادلة)

5. Metode Drill ${ }^{16}$ atau latihan siap dengan uslub terapan (التعبير على الأساليب (التنجير (التطبيقية

6. Bermain (اللعبية). ${ }^{17}$

Dalam pembelajarn metode langsung M. Abdul Hamid mengklasifikasi penerapannya sesuai dengan tingkatan anak didik dengan langkah-langkah sebagai berikut:

a. Untuk level pemula (مبتدين)

1) guru mulai melatih bicara dengan memberi pertanyaan-pertanyaan yang harus dijawab olah anak didik

2) pada saat yang bersamaan anak didik diminta untuk belajar mengucapkan kata, menyusun kalimat dan mengungkapkan pikiran

3) guru mengurutkan pertanyaan-pertanyaan yang dijawab oleh siswa sehingga berakhir membentuk sebuah tema yanhg sempurna

4) guru bisa menyuruh siswa menjawab latihan-latihan syafawiyah, mengahafal percakapan atau menjawab pertanyaan-pertanyaan yang berhubungan dengan isi teks yang elah dibaca.

b. Untuk level menengah/lanjutan (متوسطين)

1) belajar berbicara dengan bermain peran

2) berdiskusi tentang tema tertentu

3) bercerita tentang peristiwa yang terjadi pada siswa

4) bercerita tentang informasi yang telah didengar dari TV, radio atau yang lainnya.

c. Untuk level tingkat atas (متقدمين)

1) guru memilihkan tema untuk berlatih berbicara

2) tema yang dipilih hendaknya menarik dan berhubungan dengan yang kehidupan anak didik

3) tema harus jelas dan terbatas

4) mempersilahkan anak didik memilih dua tema atau lebih sampai akhirnya siswa bebas memilih tema yang dibicarakan tentang apa yang mereka ketahui. ${ }^{18}$

${ }^{15}$ Lihat Abdul 'Alim Ibrahim, al-Muwajjah al-Fannī li Mudarris al-Lughah al- 'Arabiyyah fì Turuq al-Tadrīs (Cet. X; Kairo: Dār al-Ma'ārif, 1968), h. 154-158. Lihat juga, Mahmud Isma’il Shina, h. $155-157$.

${ }^{16}$ Metode Drill (teknik latihan siap) pada umumnya digunakan untuk memperoleh suatu ketangkasan atau keterampilan dari apa yang telah dipelajari, dengan prinsip: diberikan pemahaman lebih awal sebelum diadakn latihan tertentu, kemudian proses latihan hendaknya mendahulukan hal-hal yang esensial dan berguna. Lebih lanjut lihat, AhamadSabri, Strategi Belajar Mengajar dan Micro Teaching (Cet. II; Ciputat: Quantum Teaching, 2007), h. 60-61.

${ }^{17}$ Lihat Umi Machmudah, Abdul Wahab Rosyidi, Active Learning dalam Pembelajaran Bahasa Arab (Cet. I; malang: UIN-Malang, 2008), h. 124, 138,177. Lihat juga, Mahmud Isma'il Shina, h. 253-255.

${ }^{18}$ M. Abdul Hamid, et al., Pembelajaran Bahasa Arab: Pendekatan. Metode, Strategi , Materi dan Media (Cet. I; Malang: UIN-Malang Press, 2008), h. 42-43. 
Pada intinya, teknik atau strategi yang akan diterapkan tergantung kepada guru karena pengaturan, penyusunan dan gaya mengajar sangat tergantung kepada guru serta keterampilan kepribadian guru dalam mengelola kelas, karena semua hal tersebut akan dipengaruhi oleh perbedaan situasi dan kondisi. Jadi, berhasil tidaknya metode yang diterapkan, tergantung kepada sang guru dalam mengelola kelas serta kekreatifitasan sang guru dalam mengambil teknik pengajaran yang terbaik yang cocok untuk situasi dan kondisi pengajaran.

\section{E. Kelebihan dan Kelemahan Metode Langsung (لطريقة المباشرة)}

Metode langsung atau metode mubasyarah dalam hal ini tidak menafikan kelebihan dan kelemahannya dalam penerapannya, karena semua metode saling melengkapi dalam merealisasikan tujuan pembelajaran yang ditempuh dengan sistem Pembelajaran Aktif, Inovatif, Kreatif, Efektif dan Menyenangkan (PAIKEM).

Berikut kelebihan dan kelemahan pembelajaran aktif dengan menggunakan metode langsung, sebagai berikut:

Keunggulan metode langsung antara lain:

1. Siswa terampil menyimak dan berbicara karena mereka mendapat banyak latihan dalam bercakap-cakap, khususnya mengenai topik-topik yang sudah dilatih dalam kelas.

2. Siswa mengusai pelafalan dengan baik seperti atau mendekati penutur asli.

3. Siswa mengetahui banyak kosa kata dan pemakaiannya dalam kalimat.

4. Siswa memiliki keberanian dan spontanitas dalam berkomunikasi karena sejak awal telah dilatih untuk berpikir dalam bahasa target sehingga tidak terhambat oleh proses penerjemahan.

5. Siswa menguasai tata bahasa secara fungsional tidak sekedar teoritis, artinya berfungsi untuk mengkontrol kebenaran ujarannya.

Kelemahan metode langsung antara lain:

1. Kemampuan pelajar dalam membaca untuk pemahaman lemah, karena materi dan latihan yang disediakan lebih menekankan pada keterampilan berbahasa lisan.

2. Menuntut para guru yang ideal dari segi keterampilan berbahasa (mempunyai kelancaran berbicara seperti atau mendekati penutur asli) dan kelincahan dalam penyajian pelajaran.

3. Mempunyai prinsip-prinsip yang lebih tepat untuk digunakan dalam kelas kecil yang jumlah pelajarnya tidak banyak (kurang dari 20 siswa).

4. Terbuangnya waktu untuk menjelaskan makna satu kata abstrak.

5. Terlalu membesar-besarkan persamaan antara pemerolehan bahasa pertama dan kedua. ${ }^{19}$

\section{F. Kesimpulan}

1. Metode Langsung dalam bahasa Arab disebut sebagai al-tharīqah al-mubāsyarah atau direct method dlam bahasa Inggris yaitu suatu cara menyajikan materi bahasa asing di mana bahasa Arab sebagai bahasa pengantar bagi sang guru tanpa

${ }^{19}$ Aziz Fachrurrazi, Pembelajaran Bahasa Asing, (Jakarta Timur: Bania Publishing, 2000), hal. 59-61 
menggunakan bahasa anak didik sedikit pun dalam mengajar dengan menekankan pada aspek penuturan yang benar (al-nutq al-şālih). Sehingga jika ada suatu kata yang sulit dimengerti oleh anak didik maka guru mengartikan dengan menggunakan alat peraga, mendemonstrasikan atau menggambarkannya.

2. Metode Langsung ini muncul pada abad ke 19 dan berkembang pada abad ke 20 . Karena metode ini mempunyai pemikiran baru sehingga berlawanan dengan metode qowa'id dan terjemah yang digunakan oleh para pemula dalam belajar bahasa. Metode langsung dikembangkan oleh carles berlitz, seorang ahli dalam pengajaran bahasa, di Jerman .

3. Banyak teknik atau strategi yang bisa diterapkan dalam menggunakan metode langsung, yaitu: Tanya jawab, bermain peran (dramatisasi), percakapan, diskusi/debat aktif, metode drill atau latihan siap dengan uslub terapan dan bermain.

4. Metode langsung atau metode mubasyarah dalam hal ini tidak menafikan kelebihan dan kelemahannya dalam penerapannya, karena semua metode saling melengkapi dalam merealisasikan tujuan pembelajaran yang ditempuh dengan sistem Pembelajaran Aktif, Inovatif, Kreatif, Efektif dan Menyenangkan (PAIKEM). 


\section{DAFTAR PUSTAKA}

Al-Butānī, Muhammad Saleh bin Syamsuri. al-Ta'bīr al-Muwajjah 'al al-Asālīb alSyāi'ah al-Isti'māl .Jilid I, Cet. I; Makassar: t.p., 2006.

Effendy, Ahmad Fuad. Metodologi Pengajaran Bahasa Arab (Cet. IV; Malang: Misykat, 2009.

Fachrurrazi, Aziz. Pembelajaran Bahasa Asing.Jakarta Timur: Bania Publishing, 2000.

Hamid, M. Abdul et al. Pembelajaran Bahasa Arab: Pendekatan. Metode, Strategi, Materi dan Media . Cet. I; Malang: UIN-Malang Press, 2008.

Hidayat, Yayat. Studi Prinsip Dasar Metode Pengajaran Bahasa Arab, pada http://arabicforall.or.id/metode/studi-prinsip-dasar-metode-pengajaran-bahasa$\underline{\mathrm{arab} /}$

Husain, Mukhtar Thohir. Ta'lìm al-'Arabiyyah li ghair al-Nātiqīna bihā, (Haram: Dar al-Alamiyah.

Ibrahim, Abdul 'Alim. al-Muwajjah al-Fannī li Mudarris al-Lughah al-'Arabiyyah fĩ Turuq al-Tadrīs .Cet. X; Kairo: Dār al-Ma’ārif, 1968.

Izzan, Ahmad. Metodologi Pembelajaran Bahasa Arab. Bandung: Humaniora, 2009.

Machmudah, Umi. Abdul Wahab Rosyidi, Active Learning dalam Pembelajaran Bahasa Arab.Cet. I; malang: UIN-Malang, 2008.

Makruf, Imam. Strategi Pembelajaran Bahasa Arab Aktif .Cet. I; Semarang: Need's Press, 2009.

Sabri, Ahmad. Strategi Belajar Mengajar dan Micro Teaching. Cet. II; Ciputat: Quantum Teaching, 2007.

Shina, Mahmud Isma'il. et al., Murs\id al-Mu'allim fī Tadrīs al-Lughah al-'Arabiyyah li ghair al-Nātiqīna bihā .Cet. II; t.tp: Maktab al-Tarbiyyah al'Arabī li Dual al-Khalīj.

Tu'aimah, Rusdi Ahmad. Ta'līm al- 'Arabiyyah li ghair al-Nātiqīna bihā: manāhijuhu wa asālībuhu. Mesir: ISESCO \& WICS, 1410 H - 1989 M. 